\begin{abstract}
Aleksandra Hadžić ${ }^{1}$
https://orcid.org/0000-

0003-4473-9299

Department of Psycholo-

gy, Faculty of Philosophy, University of Banja Luka
\end{abstract}

\section{Dejan Kantar}

https://orcid.org/00000002-2069-4164

Department of Psycholo-

gy, Faculty of Philosophy, University of Banja Luka

Copyright: (C) 2021

Hadžić \& Kantar. This is an open access article distributed under the terms of the Creative Commons Attribution License, which permits unrestricted use, distribution, and reproduction in any medium, provided the original author and source are credited.

1 Corresponding author email: aleksandra.hadzic@ ff.unibl.org

Received: 23.03.2021. Correction received: 10.06.2021.

Accepted: 11.06.2021.

\section{THE RELATIONSHIPS BETWEEN} ATTACHMENT DIMENSIONS AND AFFECT IN ADULTHOOD: THE MEDIATING EFFECTS OF PSYCHOLOGICAL FLEXIBILITY

This research was conducted during the state of emergency in response to coronavirus pandemic with the aim to further examine the relationships between attachment dimensions - attachment anxiety and attachment avoidance - and affect and to test the mediating role of psychological flexibility in these relationships. The sample which was obtained by using the snowball sampling method consists of 1515 adults $(70.4 \%$ females) from the Republic of Srpska, entity of Bosnia and Herzegovina, aged between 18 and 65 who filled a relatively short form of an online set of questionnaires. Attachment dimen-sions were measured by the Relationship Questionnaire (RQ), affect by the Negative and Positive Affect Scale (NAPAS), and psychological flexibility by the Acceptance and Action Questionnaire (AAQ-II). The results indicate that attachment anxiety and attachment avoidance correlate positively with the negative affect and correlate negatively with the positive affect. Furthermore, the results showed that the relationships between attachment dimensions and negative affect can be explained through psychological flexibility higher values of attachment dimensions contribute to lower psychological flexibility, which then leads to higher negative affect. The mediatory role of psychological flexibility is not determined in the relation between attachment dimensions and positive affect. The obtained findings have been considered in the light of theoretical and practical importance.

Key words: attachment dimensions, psychological flexibility, positive and negative affect, adulthood 


\section{Introduction}

Right after the introduction of the emergency situation due to the coronavirus pandemic, in the beginning of April 2020, Republic of Srpska declared the state of emergency. Measures in this entity were stricter than in other parts of Bosnia and Herzegovina and were established almost a month earlier. This meant introducing a series of measures which limited movement and prohibited assembling of citizens with the intention to reduce the possibility of virus transmission. Though for the purposes of public welfare, these measures, combined with the fear of infection and worry for the future, can prove to have a strong influence on the population's everyday life and their mental health (Brooks et al., 2020), making the entire context of fighting a new and unknown virus a potential source of many unpleasant experiences.

It is a common opinion that unpleasant experiences are followed by the emotions of the same quality since they are natural and adaptive answers to stressful events. However, pleasant emotions during difficult circumstances also aren't an unusual occurrence - they are spotted among people going through numerous major stressful life events and also among those experiencing stress on a daily basis (Ong et al., 2006). Emotions such as happiness, contentment and joy are displayed together with the unpleasant ones and, most importantly, have a unique effect on physical and psychological well-being (Folkman, 2007; Folkman \& Moskowitz, 2000). It is established that persons with the tendency of experiencing more positive emotions are less prone to the influence of stressful experiences (Fredrickson, 2001; Fredrickson \& Joiner, 2002; Zautra et al., 2005), which can be conceptually and empirically correlated with certain characteristics of secure attachment.

According to attachment theory, people are born with a psychobiological system which motivates them to seek proximity to significant others in times of stress (Bowlby, 1988). Frequent experiences with persons who are available and responsive in times when help is needed promote a relatively stable feeling of emotional security - a perception of others as reliable, caring and trustworthy, and themselves as appreciated and competent (that is, a positive model of others and self). As opposed to that, experiences with persons who don't react, reject or offer inconsistent answers encourage a development of insecure attachment - a perception of others as unreliable (i.e., a negative model of others) and/or perceiving oneself as unworthy and inefficient (i.e., a negative model of self). These early experiences serve as a pattern for the development of later interpersonal relationships, and it is believed they affect the way in which an individual experiences, processes and expresses emotions in all aspects of their life (Bretherton \& Munholland, 1999).

Even though there is a wide variety of conceptualizations and ways of measuring attachment, individual differences in adults are mostly defined through variations in two dimensions - attachment anxiety and attachment avoidance, which characterize the quality of relationship (Brennan et al., 
1998). Attachment anxiety represents the fear of being rejected and abandoned, while attachment avoidance represents the tendency to avoid closeness and dependence on others in a relationship. Low values in both dimensions suggest secure attachment, while high values in one or both dimensions indicate an insecure attachment.

Many different studies show that insecure attachment, especially the one characterized by anxiety, is connected with various indicators of poor mental health, and has gained a status of a vulnerability factor in the development of emotional problems and dysfunctional behaviors, while secure attachment is recognized as a protective factor which helps the development of emotional stability, subjective well-being and resilience (Mikulincer \& Florian, 2003; Mikulincer \& Shaver, 2016). Apart from studying the relationships of (in)secure attachments and different parameters of mental health (Mikulincer \& Shaver, 2016), a growing number of researchers focus on examining the potential mediators, i.e., variables which mediate in those relationships and explain the perceived effects. Psychological flexibility is one of the concepts that drew their attention relatively recently. It developed as a part of Acceptance and commitment therapy (ACT) and represents ability of humans as rational and aware beings to interact with the present more fully, i.e., to accept unpleasant conditions (thoughts, emotions, sensations and memories) without any defence or control, in order to realize important goals and live according to personal values (Bond et al., 2011; Hayes et al., 2006). On the contrary, psychological inflexibility implies a rigid domination of behaviors which are not in accordance with personal values and goals, which often happens when people believe in the literal meaning of their own thoughts, making them their only possible reality (cognitive fusion), that is, when they wish to avoid unpleasant inner conditions and context which made them happen (experiential avoidance). Cognitive fusion and experiential avoidance, according to some authors (e.g., Calvo et al., 2020), can be brought into a relationship with typical regulatory strategies which are used by insecurely attached persons. On the one hand, they believe that dealing with difficulties is only possible if they rely solely on themselves, and perceive unpleasant emotions such as fear, anxiety, anger, sadness and guilt as the characteristics of sensitive people, which is the opposite of the way in which they perceive themselves, so they tend to repress and deny these emotions, even when their physiological indicators are evident (attachment avoidance is expressed), or, on the other hand, being too sensitive to rejection they experience their unpleasant emotions more intensely, and regulate them with strategies which only further intensify them and make them escalate, thus capturing the attention of a close person (attachment anxiety is expressed). Compared to this, securely attached persons are able to regulate these emotions with the use of a wide spectrum of strategies, including relying on emotional and social support of close persons, so that the problems they face are mostly perceived as challenges which are manageable and not as elusive threats (Collins, 1996; Garrison et al., 2014; Mikulincer \& Shaver, 2016). In 
this respect, psychological flexibility could be viewed as one of the strategies employed by securely attached persons, since it benefits psychological and emotional well-being (Kashdan \& Rottenberg, 2010; Wolgast, 2014), the constructs which are related to this quality of attachment.

Although it is believed that the attachment style affect emotional experiences in all aspects of life, the relations of these phenomena are usually viewed in the context of specific close relations (e.g., attachment style in romantic relationship) and/or problems which potentially affect their dynamic (e.g., Meuwly \& Davila, 2019; Simpson \& Rholes, 2017; Wei et al., 2005). There are far less studies which put individual differences with regarding the general qualities of attachment and subjective states in broader context. In one such research concerning the evaluation of everyday, common, emotional experiences (Torquati \& Raffaelli, 2004), it has been established that securely and insecurely attached persons, independent of the type of relation, differ from one another regarding experiencing specific strong emotions. In fact, securely attached individuals specified their experiences of certain strong pleasant emotions more often, while insecurely attached ones highlighted their experiences of certain strong unpleasant emotions. However, the differences were not spotted in regards to the general tendency of experiencing pleasant affective conditions, that is, positive affect, nor have they been seen through the subtypes of insecure attachment, or after having considered the negative affect (the general tendency of experiencing unpleasant affective states). In some other studies, however, the connections between attachment dimensions and both types of affect negative correlation with positive affect and positive correlation with negative affect, have been observed, but have been perceived as unstable when tested on different samples (Barry et al., 2007). Since these evaluations were based on small sample sizes, the authors have suggested further research in order to create a clearer picture of the relations between the quality of attachment and general affective tendencies.

With regards to this, the goal of this paper is focused on the further examination of the attachment relations and affect among adult population from the Republic of Srpska during the state of emergency. This context seems appropriate since the circumstances that follow this pandemic represent a potential trigger to attachment system, and therefore to the variables which are conceptually and empirically connected to the system.

Having in mind the setup of attachment theory and the findings of abovementioned studies, it is expected that the characteristics of secure attachment will be connected with positive affect, and that characteristics of insecure attachment will be connected with negative affect, while it is possible that the strengths of connections differ depending on the type of the attachment dimensions. Besides, since there are studies which bring into connection the qualities of attachment and variables from the domain of emotional reaction with the characteristics of psychological flexibility, as aforementioned, the other goal is to examine whether the potential effects of attachment dimen- 
sions on positive and negative affect can be explained indirectly - through psychological flexibility. In this way, we not only get a clearer picture of the relations of these variables, but also the understanding of possible modalities of psychotherapeutic action.

\section{Method}

\section{Sample}

The sample which was obtained by using the snowball sampling method consists of 1515 adults (70.4\% females) from the Republic of Srpska, entity of Bosnia and Herzegovina, aged between 18 and 65 ( $M d n=22, M=27.58, S D=$ 10.91), who have completed a relatively short form of an online set of questionnaires. The research was conducted voluntarily and anonymously between April 28th and May 20th 2020, i.e., the period of the state of emergency on the territory of the Republic of Srpska, precisely one month after the declaring of the state of emergency and introduction of the first measures to prevent the spread of the coronavirus. During the state of emergency the measures changed frequently. Many of them, such as the closure of educational institutions and switching to online mode, stringent measures for public gatherings, the special working regime of markets and pharmacies, mandatory wearing face masks in open and closed spaces, self-isolation and „stay at home” campaigns etc., were still active in the data collection period.

\section{Instruments}

\section{The Relationships Questionnaire (RQ)}

RQ (Bartholomew \& Horowitz, 1991) is a simple instrument with good metric characteristics (Scharfe \& Bartholomew, 1994). It consists of four descriptions, one for each of four attachment styles - secure, dismissive, preoccupied and fearful. The participants choose one of those which, in their opinion, best describes them, while also ranking every description on the scale from 1 (completely unrelated to me) to 7 (completely related to me). Based on this instrument's results we can gather several pieces of information - the style which the participants ranked as best describing them, values for the model of self and the model of other, that is, for attachment anxiety and attachment avoidance. The model of self is calculated by summing the values of scores in the forms which have a positive model of self (secure and dismissive), after which the value of circled scores which have a negative model of self (fearful and preoccupied) are subtracted from the value of positive scores. The model of others is calculated by adding the scores on the forms which have positive model of others (secure and preoccupied), after which the value of circled scores with the negative model of others (dismissing and fearful) are 
subtracted from the value of positive scores. If we want to view the data from the perspective of attachment anxiety and attachment avoidance, which is a far more precise and desirable way of considering individual differences (Fraley et al., 2015), the calculation is somewhat different - the minuend from the previous formula becomes the subtrahend and vice versa. In order to avoid negative values, the received data is recoded in a way that values range from 1 and 25 , bearing in mind that higher values indicate a more expressed anxiety, i.e., more expressed avoidance. The questionnaire scores showed medium test-retest stability in previous research (Scharfe \& Bartholomew, 1994) and were highly correlated with other self-report measures of attachment style (Schmitt et al., 2004; Stein et al., 2010).

\section{The Short version of the Negative and Positive Affect Scale (NAPAS)}

NAPAS (Joshanloo, 2017) consists of five positive and five negative affective states of low and high levels of excitations, where the participants estimate how often they have experienced each condition in the last thirty days, using a scale from 1 (never) to 5 (always). A complete result in each subscale can vary in a range from 5 to 25. The instrument has been translated from English using the double translation method (Van de Vijver \& Hambleton, 1996), and with a confirmative factor analysis the original two-factor structure is confirmed, with good model-data fit indices $\left(\chi^{2}(34)=288, p<.001, C F I=.96, T L I=.95\right.$, $R M S E A=.07,90 \% C I[.063, .078], S R M R=.04)$. Good indicators of internal consistency are also obtained (negative affect: .84 and $\omega=.84$; positive affect: $\alpha=$ .85 and $\omega=.87)$.

\section{The Acceptance and Action Questionnaire (AQS 2)}

AQS 2 (Bond et al., 2011; adapted by Žuljević, Rakočević, \& Krnetić, 2020) represents a measure of psychological flexibility and it consists of seven claims. The participants provide the answers using a seven point Likert scale (from never to always), choosing the value which reflects the degree of their agreement with each individual claim. The overall result can vary in a range from 7 to 49. For easier interpretation of the data, the values on the scale are recoded in such way that higher values indicate a more expressed psychological flexibility. Excellent indicators of internal consistency are obtained for this scale $(\alpha=.90$ and $\omega=.91)$. 


\section{Results}

The results of descriptive statistics for variables used in the research are shown in Table 1 . The values of skewness and kurtosis vary within the recommended range ( \pm 1.5 ; Tabachnick \& Fidell, 2013).

Before introducing the intercorrelations of variables, something that needs to be pointed out is that the sample in this research wasn't homogenized regarding the sex (70.4\% female), and that almost three quarters of the participants were under the age of thirty (74.6\%), meaning that in the preliminary analysis, the potential effects of sex and age have been examined. Statistically significant, but practically low effects of sex have been observed in attachment anxiety $\left(M_{\mathrm{f}}\right.$ $\left.=10.71, S D_{\mathrm{f}}=3.83 ; M_{\mathrm{M}}=11.21, S D_{\mathrm{M}}=3.70 ; t(1513)=-2.37, p=.018, d=0.13\right)$, psychological flexibility $\left(M_{\mathrm{f}}=38.66, S D_{\mathrm{f}}=7.60 ; M_{\mathrm{M}}=40.94, S D_{\mathrm{M}}=7.10 ; t(1513)\right.$ $=-5.44, p<.001, d=0.31)$ and negative affect $\left(M_{\mathrm{f}}=11.05, S D_{\mathrm{f}}=3.80 ; M_{\mathrm{M}}=10.03\right.$, $\left.S D_{\mathrm{M}}=3.68 ; t(1513)=4.81, p<.001, d=0.27\right)$, while between the age and attachment avoidance $(r=-.12, p<.01)$, that is age and negative affect $(r=-.10, p$ $<.01$ ), statistically significant correlations of low intensity have been recorded. In further analysis the effect of these variables has been controlled, primarily because of the sample structure, but also with the aims of the research. So, the coefficients of partial correlations have been shown in Table 1 apart from the results of descriptive statistics. All tested relations have showed their statistical significance, given that in the case of the relation between attachment dimensions and other variables, the correlations seem to be stronger when referring to attachment anxiety. As expected, attachment anxiety and attachment avoidance correlate negatively with positive affect and positively with negative affect. Although generally speaking the identified correlations have smaller strength, they significantly differ statistically $z_{p a}=3.97, \mathrm{p}<.001$ and $z_{n a}=5.27, \mathrm{p}<$ .001). Besides the fact that they correlate weakly with one another, attachment dimensions correlate negatively with psychological flexibility (attachment anxiety moderately, and attachment avoidance weakly), while it is in a low positive correlation with positive affect and a relatively high negative correlation with negative affect. A moderate negative correlation between the affect was noticed.

Table 1

Descriptive statistics and the results of partial correlation analysis

\begin{tabular}{lllllllll}
\hline & $M$ & $S D$ & $S k$ & $K u$ & 1. & 2. & 3. & 4. \\
\hline 1. Attachment anxiety & 10.86 & 3.80 & 0.16 & 0.04 & - & & & \\
2. Attachment avoidance & 12.29 & 3.76 & 0.34 & 0.06 & $.13^{* *}$ & - & & \\
3. Psychological flexibility & 39.33 & 7.52 & -0.93 & 0.65 & $-.44^{* *}$ & $-.19^{* *}$ & - & \\
4. Positive affect & 16.64 & 3.65 & -0.29 & 0.02 & $-.27^{* *}$ & $-.14^{* *}$ & $.34^{* *}$ & - \\
5. Negative affect & 10.75 & 3.79 & 0.62 & 0.01 & $.33^{* *}$ & $.16^{* *}$ & $-.61^{* *}$ & $-.44^{* *}$ \\
\hline
\end{tabular}

Notes. $M$ - mean; $S D$ - standard deviation; $S k$ - skewness; $K u$ - kurtosis.

${ }^{* *} \mathrm{p}<.01$. 
In order to examine the mediating role of psychological flexibility in relation to attachment dimensions and affect, four models have been tested by using the PROCESS macro for SPSS (c. tables 2-5), given that the evaluation of indirect effect $(a \times b)$ has been based on bootstrap method with 5000 repeat samples (recommendation c. Hayes, 2013). In each of the tested models, one attachment dimension was set as a predictor, psychological flexibility was set as a mediator and one affect per each of the tested models was used as a criterion. With regards to the formerly observed effects, the effects of other variables have been controlled - sex, age, and the variables which were not the subject of the concrete analysis in the given model - the other attachment dimension and the other affect quality.

Attachment anxiety was used as a predictor in the first model, and positive affect as a criterion. Besides the effects of sex and age, the effects of attachment avoidance and negative affect have been controlled in this model. The results are shown in Table 2.

Table 2

Psychological flexibility as a mediator between attachment anxiety and positive affect

\begin{tabular}{lcccccc}
\hline & $B$ & $S E$ & $t$ & $p$ & \multicolumn{2}{c}{$95 \%$ CI } \\
\hline Direct effect $\left(c^{\prime}\right)$ & -0.11 & .02 & -4.62 & $<.001$ & {$[-.16$,} & $-.06]$ \\
Indirect effect $(a \times b)$ & -0.01 & .01 & - & - & {$[-.03$,} & $.00]$ \\
Effect $a$ & -0.50 & .04 & -12.49 & $<.001$ & {$[-.58$,} & $-.42]$ \\
Effect $b$ & 0.03 & .01 & 1.89 & .06 & {$[.00$,} & $.06]$ \\
Total effect $(c)$ & -0.13 & .02 & -5.45 & $<.001$ & {$[-.17$,} & $-.08]$ \\
\hline
\end{tabular}

Notes. $B$ - unstandardised regression coefficient; $S E$ - standard error; $p$ - level of significance; $C I$ - confidence interval. The statistical significance of the indirect effect is evaluated based on the upper and lower limit of the confidence interval. The indirect effect is considered statistically significant if the confidence interval does not include the value 0 .

Based on the presented results one can notice that attachment anxiety $(c)$ significantly predicts the positive affect when the mediator effect is held under control, with potential effects of sex, age, attachment avoidance and negative affect. However, that relation cannot be explained by mediation of psychological flexibility $(a \times b)$ as well since the confidence interval of the indirect effect includes the value 0 . This trend - significant direct, but not significant indirect effect - has been observed when, instead of attachment anxiety as a predictor, attachment avoidance served that purpose, while the criterion, with the control of all the rest of the variables, remains the same (Table 3). Based on these two test results we can conclude that lower values of attachment dimensions predict a stronger positive affect, given that the relations between these 
variables aren't mediated with psychological flexibility. Approximately $22 \%$ of variance in positive affect was explained by the variables in both models since the same variables were included in them $\left(R^{2}=.22, F(6,1508)=71.76, p<\right.$ $.001)$.

Table 3

Psychological flexibility as a mediator between attachment avoidance and positive affect

\begin{tabular}{lcccccc}
\hline & $B$ & $S E$ & $t$ & $p$ & \multicolumn{2}{c}{$95 \% C I$} \\
\hline Direct effect $\left(c^{\prime}\right)$ & -0.05 & .02 & -2.40 & .02 & {$[-.10$,} & $-.01]$ \\
Indirect effect $(a \times b)$ & 0.00 & .00 & - & - & {$[-.01$,} & $.00]$ \\
Effect $a$ & -0.16 & .04 & -3.99 & $<.001$ & {$[-.23$,} & $-.08]$ \\
Effect $b$ & 0.03 & .01 & 1.89 & .06 & {$[.00$,} & $.06]$ \\
Total effect $(c)$ & -0.06 & .02 & -2.60 & .01 & {$[-.10$,} & $-.01]$ \\
\hline
\end{tabular}

Notes. $B$ - unstandardised regression coefficient; $S E$ - standard error; $p$ - level of significance; $C I$ - confidence interval. The statistical significance of the indirect effect is evaluated based on the upper and lower limit of the confidence interval. The indirect effect is considered statistically significant if the confidence interval does not include the value 0 .

On the other hand, significant mediation effects of the psychological flexibility have been observed in the relations between attachment dimensions and negative affect (Tables 4 and 5). In both cases, when attachment anxiety and attachment avoidance were used as predictors and the effects of other variables were controlled, the effects which have been labelled as full meditation before the contemporary approach to testing (Hayes, 2013), have been obtained. In other words, statistically significant indirect, but not direct effects were identified, which tells us that the relations between these variables are mediated by psychological flexibility, in such way that higher values on attachment dimensions contribute to a weaker psychological flexibility (effects $a$ ), which in turn results with stronger negative affect (effects $b$ ). In this way we can explain about $45 \%$ of the variance in negative affect, bearing in mind that the same variables were included in both mediation models $\left(R^{2}=.45, F(6\right.$, 1508) $=205.80, p<.001$ ). 
Table 4

Psychological flexibility as a mediator between attachment anxiety and negative affect

\begin{tabular}{lcccccc}
\hline & $B$ & $S E$ & $t$ & $p$ & \multicolumn{2}{c}{$95 \% C I$} \\
\hline Direct effect $\left(c^{\prime}\right)$ & 0.04 & .02 & 1.79 & .07 & {$[.00$,} & $.08]$ \\
Indirect effect $(a \times b)$ & 0.18 & .02 & - & - & {$[.15$,} & $.21]$ \\
Effect $a$ & -0.71 & .05 & -15.58 & $<.001$ & {$[-.80$,} & $-.62]$ \\
Effect $b$ & -0.26 & .01 & -22.68 & $<.001$ & {$[-.28$,} & $-.23]$ \\
Total effect $(c)$ & 0.22 & .02 & 9.53 & $<.001$ & {$[.17$,} & $.26]$ \\
\hline
\end{tabular}

Notes. $B$ - unstandardised regression coefficient; $S E$ - standard error; $p$ - level of significance; $C I$ - confidence interval. The statistical significance of the indirect effect is evaluated based on the upper and lower limit of the confidence interval. The indirect effect is considered statistically significant if the confidence interval does not include the value 0 .

Table 5

Psychological flexibility as a mediator between attachment avoidance and negative affect

\begin{tabular}{lcccccc}
\hline & $B$ & $S E$ & $t$ & $p$ & \multicolumn{2}{c}{$95 \%$ CI } \\
\hline Direct effect $\left(c^{\prime}\right)$ & 0.02 & .02 & 0.99 & .32 & {$[-.02$,} & $.06]$ \\
Indirect effect $(a \times b)$ & 0.06 & .01 & - & - & {$[.03$,} & $.08]$ \\
Effect $a$ & -0.23 & .04 & -5.08 & $<.001$ & {$[-.32$,} & $-.14]$ \\
Effect $b$ & -0.26 & .01 & -22.68 & $<.001$ & {$[-.28$,} & $-.23]$ \\
Total effect $(c)$ & 0.08 & .02 & 3.42 & $<.001$ & {$[.03$,} & $.12]$ \\
\hline
\end{tabular}

Notes. $B$ - unstandardised regression coefficient; $S E$ - standard error; $p$ - level of significance; $C I$ - confidence interval. The statistical significance of the indirect effect is evaluated based on the upper and lower limit of the confidence interval. The indirect effect is considered statistically significant if the confidence interval does not include the value 0 .

\section{Discussion and conclusion}

The research was conducted in the Republic of Srpska one month after the implementation of the emergency situation and the introduction of first measures of prevention due to the pandemic caused by coronavirus, with the goal of further examining the relations between attachment dimensions and affect and to test the mediatory role of psychological flexibility in these relations. Considering the role of attachment and the mechanisms through which it achieves its effect on numerous aspects of psychological functioning in 
the context of various crisis situations, especially this one, which by itself is specific, can help better understand the potential ways to prevent unwanted outcomes and to determine therapeutic action.

The obtained results confirm the relation between attachment and affect. It has been shown that the characteristics of secure attachment - lower anxiety and lower avoidance - are followed by a stronger positive affect, and the characteristics of insecure attachment - high anxiety and high avoidance - are followed by a stronger negative affect, which is in accordance with the theory and with the findings of earlier studies (Barry et al., 2007). Even though these connections have, generally speaking, a lower intensity, they are the most expressed, as expected, in the case of attachment anxiety, given that avoidance-prone persons are more likely to repress and deny emotions. On the other hand, if we take into account the opinion according to which repression and denial help avoidant attached persons keep optimal levels of well-being in everyday life, as well as in extremely stressful conditions, these strategies become inefficient, so that even the people who use them experience stress in the same way as other types of insecurely attached persons (Edelstein \& Shaver, 2004). To a certain degree, the results indirectly suggest that the participants of this research did not experience the state of emergency and implemented restrictive measures due to coronavirus pandemic as very stressful. These kinds of findings are already mentioned in some reviewed works, but the authors don't deny the possibility of the unwanted outcomes of isolation and the accompanying circumstances being uncovered after a few months or years as they end (Brooks et al., 2020).

When talking about the analysis in which the mediation effect of psychological flexibility was researched, it has been determined that the relations between attachment dimensions and affect are mediated by this psychological mechanism only in the case of negative affect. Namely, it was shown that persons with a more expressed fear of rejection and abandonment, as well as tendency to avoid closeness and dependability in relationships, are more prone to the negative affect because of their psychological inflexibility. On the other hand, the mediatory role of psychological flexibility is not determined in the relation between attachment dimensions and positive affect. Broadly viewed, these results show that early attachment, as a primary context of learning to control one's own emotions (Bowlby, 1988), finds different ways of acting over time, which can be recognized in adulthood. Numerous papers point out a wide spectrum of possible ways (e.g., Čačić \& Gavrilov Jerković, 2013; Wei et al., 2005) and this research confirmed another one used for the negative affect. The connection between attachment and positive affect is evidently manifested through the mediation of other mechanism. These findings are not unusual, since psychological flexibility does not problematize pleasant emotions, but it rather entails people's ability to actively and conscientiously accept their unpleasant inner experiences and reactions, without the intention of changing them. The need for control and avoid them, which is at the same time the 
core characteristic of insecurely attached persons, often becomes the source of the problem, rather than its solution. The fact that the attempts to release unpleasant emotions and thoughts only increase their frequency, strength and duration goes in favor of that (Wegner, 1994).

The obtained results are in accordance with the point of view that positive and negative affect do not represent polar opposites of one bipolar dimension, but rather that they phenomenologically differ (e.g., Feldman Barrett \& Russell, 1998). Bearing that in mind, it should be mentioned that the instrument used in this research for measuring affect comprised of a small number of different conditions, with some conditions characterized by an extremely low level of excitation. It is possible that a clearer picture of emotional reaction would have been gained if those conditions that people have experienced in a quarantine, such as anger, fear, frustration, helplessness, loneliness, nervousness and worry, were included (Brooks et al., 2020). However, since the intention was to collect the largest possible sample during the state of emergency in order to implement the research aims and to keep participants motivated and pre-vent their giving up on the research, especially bear in mind the fact that the questionnaires were set online and we had no possibility to affect their motiva-tion, simpler instruments were used. The broader picture could be obtained in future research by collecting an equal sample in terms of sex and age, since it would be possible to examine sex and age differences seen in this research.

As it turns out, by including the concept of psychological flexibility in the research of attachment relations and affect, one can get a clearer picture of their relations. However, the obtained findings not only further point out the complexity of attachment itself, but also potentially offer another important mechanism of psychotherapeutic change. If, in fact, attachment is viewed as a relatively stable characteristic of personality, and psychological flexibility as an ability which is learned and developed, one can conclude that working on flexibility represents a potentially simpler solution than changing basic personal beliefs, such as one's view of self and others.

\section{Conflict of interest}

We have no conflicts of interest to disclose.

\section{Data availability statement}

The datasets presented in this study can be found in online repositories. This data can be found here: https://osf.io/5gpbm/. 


\section{References}

Barry, R. A., Lakey, B., \& Orehek, E. (2007). Links among attachment dimensions, affect, the self, and perceived support for broadly generalized attachment styles and specific bonds. Personality and Social Psychology Bulletin, 33(3), 340-353. https://doi.org/10.1177/0146167206296102

Bartholomew, K., \& Horowitz, L. M. (1991). Attachment styles among young adults: A test of a four-category model. Journal of Personality and Social Psychology, 61(2), 226-244. https://doi.org/10.1037/0022-3514.61.2.226

Bond, F. W., Hayes, S. C., Baer, R. A., Carpenter, K. M., Guenole, N., Orcutt, H. K., Waltz, T., \& Zettle, R. D. (2011). Preliminary psychometric properties of the Acceptance and Action Questionnaire - II: A revised measure of psychological flexibility and experiential avoidance. Behavior Therapy, 42(4), 676-688. https://doi.org/10.1016/j.beth.2011.03.007

Bowlby, J. (1988). A secure base: Clinical applications of attachment theory. London: Routledge.

Brennan, K. A., Clark, C. L., \& Shaver, P. R. (1998). Self-report measurement of adult attachment: An integrative overview. In J. A. Simpson \& W. S. Rholes (Eds.), Attachment theory and close relationships (pp. 46-76). New York: Guilford.

Bretherton, I., \& Munholland, K. A. (1999). Internal working models in attachment relationships: A construct revisited. In J. Cassidy \& P. R. Shaver (Eds.), Handbook of attachment: Theory, research and clinical applications (pp. 89-111). New York: Guilford Press.

Brooks, S. K., Webster, R. K., Smith, L. E., Woodland, L., Wessely, S., Greenberg, N., \& Rubin, G. J. (2020). The psychological impact of quarantine and how to reduce it: Rapid review of the evidence. The Lancet, 395(10227), 912-920. https://doi.org/10.1016/s0140-6736(20)30460-8

Calvo, V., D’Aquila, C., Rocco, D., \& Carraro, E. (2020). Attachment and well-being: Mediatory roles of mindfulness, psychological inflexibility, and resilience. Current Psychology. https://doi.org/10.1007/s12144-020-00820-2

Collins, N. L. (1996). Working models of attachment: Implications for explanation, emotion, and behavior. Journal of Personality and Social Psychology, 71(4), 810-832.https://doi.org/10.1037/0022-3514.71.4.810

Čačić, S., Gavrilov Jerković, V. (2013) Kognitivno-afektivni regulatorni mehanizmi kao medijatori između dimenzija afektivne vezanosti i depresije. [Cognitive-affective mechanisms of regulation as mediators between attachment dimensions and depression]. Primenjena psihologija, 6(4), 385405. https://doi.org/10.19090/pp.2013.4.385-405

Edelstein, R. S., \& Shaver, P. R. (2004). Avoidant attachment: Exploration of an oxymoron. In D. J. Mashek \& A. P. Aron (Eds.), Handbook of closeness and intimacy (pp. 397-412). New Jersey: Lawrence Erlbaum Associates.

Feldman Barrett, L., \& Russell, J. A. (1998). Independence and bipolarity in the structure of current affect. Journal of Personality and Social Psychology, 74(4), 967-984. https://doi.org/10.1037/0022-3514.74.4.967 
Folkman, S. (2007). The case for positive emotions in the stress process. Anxiety, Stress, \& Coping, 21(1), 3-14. https://doi.org/ doi:10.1080/10615800701740457

Folkman, S., \& Moskowitz, J. T. (2000). Positive affect and the other side of coping. American Psychologist, 55(6), 647-654. https://doi.org/10.1037/0003066X.55.6.647

Fraley, R. C., Hudson, N. W., Heffernan, M. E., \& Segal, N. (2015). Are adult attachment styles categorical or dimensional? A taxometric analysis of general and relationship-specific attachment orientations. Journal of Personality and Social Psychology, 109(2), 354-368. https://doi.org/10.1037/pspp0000027

Fredrickson, B. L. (2001). The role of positive emotions in positive psychology: The broaden-and-build theory of positive emotions. American Psychologist, 56(3), 218-226. https://doi.org/10.1037/0003-066x.56.3.218

Fredrickson, B. L., \& Joiner, T. (2002). Positive emotions trigger upward spirals toward emotional well-being. Psychological Science, 13(2), 172-175. https:// doi.org/10.1111/1467-9280.00431

Garrison, A., Kahn, J., Miller, S., \& Sauer, E. (2014). Emotional avoidance and rumination as mediators of the relation between adult attachment and emotional disclosure. Personality and Individual Differences, 70, 239-245. https://doi.org/10.1016/j.paid.2014.07.006

Hayes, A. F. (2013). Introduction to mediation, moderation, and conditional process analysis: A regression-based approach. New York: The Guilford Press

Hayes, S. C., Luoma, J. B., Bond, F. W., Masuda, A., \& Lillis, J. (2006). Acceptance and Commitment Therapy: Model, processes, and outcomes. Behaviour Research and Therapy, 44, 1-25. https://doi.org/doi:10.1016/j.brat.2005.06.006

Joshanloo, M. (2017). Factor structure and criterion validity of original and short versions of the Negative and Positive Affect Scale (NAPAS). Personality and Individual Differences, 105, 233-237. https://doi.org/10.1016/j. paid.2016.09.060

Kashdan, T. B., \& Rottenberg, J. (2010). Psychological flexibility as a fundamental aspect of health. Clinical Psychology Review, 30(7), 865-878. https://doi. org/10.1016/j.cpr.2010.03.001

Meuwly, N., \& Davila, J. (2019). Feeling bad when your partner is away. Journal of Social and Personal Relationships, 36(1) 22-42. https://doi. org/10.1177/0265407517718389

Mikulincer, M., \& Florian, V. (2003). Attachment style and affect regulation: Implications for coping with stress and mental health. In G. J. O. Fletcher \& M. S. Clark (Eds.), Blackwell Handbook of Social Psychology: Interpersonal Processes (pp. 535-557). Oxford: Blackwell Publishing.

Mikulincer, M., \& Shaver, P. R. (2016). Attachment in adulthood: Structure, dynamics, and change (2nd ed.). New York: Guilford Press.

Ong, A. D., Bergeman, C. S., Bisconti, T. L., \& Wallace, K. A. (2006). Psychological resilience, positive emotions and successful adaptation to stress in later life. Journal of Personality and Social Psychology, 91(4), 730-749. https://doi. org/10.1037/0022-3514.91.4.730 
Scharfe, E., \& Bartholomew, K. (1994). Reliability and stability of adult attachment patterns. Personal Relationships, 1(1), 23-43. https://doi. org/10.1111/j.1475-6811.1994.tb00053.x

Schmitt, D. P., Alcalay, L., Allensworth, M., Allik, J., Ault, L., Austers, I., Bennett, K. L., Bianchi, G., Boholst, F., Cunen, M. A. B., Braeckman, J., Brainerd, E. G., Jr., Caral, L. G. A., Caron, G., Casullo, M. M., Cunningham, M., Daibo, I., De Backer, C., De Souza, E., ... Zupanèiè, A. (2004). Patterns and universals of adult romantic attachment across 62 cultural regions: Are models of self and of other pancultural constructs? Journal of Cross-Cultural Psychology, 35(4), 367-402. https://doi.org/10.1177/0022022104266105

Simpson, J. A., \& Rholes, W. S. (2017). Adult attachment, stress, and romantic relationships. Current Opinion in Psychology, 13, 19-24. https://doi. org/10.1016/j.copsyc.2016.04.006

Stein, M. B., Siefert, C. J., Stewart, R. V., \& Hilsenroth, M. J. (2010). Relationship between the Social Cognition and Object Relations Scale (SCORS) and attachment style in a clinical sample. Clinical Psychology \& Psychotherapy, 18(6), 512-523. https://doi.org/10.1002/cpp.721

Tabachnick, B. G., \& Fidell, L. S. (2013). Using Multivariate Statistics (6thed.). Boston: Pearson Education.

Torquati, J. C., \& Raffaelli, M. (2004). Daily experiences of emotions and social contexts of securely and insecurely attached young adults. Journal of Adolescent Research, 19(6), 740-758. https://doi.org/10.1177/07435584 03260023

Van de Vijver, F., \& Hambleton, R. (1996). Translating tests: Some practical guidelines. European Psychologist, 1(2), 89-99. https://doi. org/10.1027/1016-9040.1.2.89

Wegner, D. M. (1994). Ironic processes of mental control. Psychological Review, 101(1), 34-52. https://doi.org/10.1037/0033-295X.101.1.34

Wei, M., Vogel, D. L., Ku, T. Y., \& Zakalik, R. A. (2005). Adult attachment, affect regulation, negative mood, and interpersonal problems: The mediating roles of emotional reactivity and emotional cutoff. Journal of Counseling Psychology, 52(1), 14-24. https://doi.org/10.1037/0022-0167.52.1.14

Wolgast, M. (2014). What does the Acceptance and Action Questionnaire (AAQ-II) really measure? Behavior Therapy, 45(6), 831-839. https://doi. org/10.1016/j.beth.2014.07.002

Zautra, A. J., Johnson, L. M., \& Davis, M. C. (2005). Positive affect as a source of resilience for women in chronic pain. Journal of Consulting and Clinical Psychology, 73(2), 212-220. https://doi.org/10.1037/0022-006x.73.2.212

Žuljević, D., Rakočević, N., \& Krnetić, I. (2020). Testing the model of psychological flexibility in the Serbian cultural context: The psychometric properties of the Acceptance and Action Questionnaire. Psihologija, 53(2), 161-181. https:// doi.org/10.2298/PSI191015006Z 


\section{Aleksandra Hadžić}

https://orcid. org/0000-0003-

4473-9299

Katedra za psihologiju, Filozofski fakultet, Univerzitet u Banjoj Luci

\section{Dejan Kantar}

https://orcid. org/0000-00022069-4164

Katedra za psihologiju, Filozofski fakultet, Univerzitet u Banjoj Luci

\section{RELACIJE DIMENZIJAAFEKTIVNE VEZANOSTI I AFEKATA U ODRASLOJ DOBI: MEDIJATORSKI EFEKTI PSIHOLOŠKE FLEKSIBILNOSTI}

Istraživanje je sprovedeno tokom vanrednog stanja za vrijeme pandemije izazvane virusom korona da bi se dodatno ispitali odnosi dimenzija afektivne vezanosti i afekata, te da bi se testirala medijatorska uloga psihološke fleksibilnosti u tim relacijama. Metodom snježne grudve (snowball sampling method) 1515 odraslih osoba (70.4\% ženskog pola) iz Republike Srpske, entiteta Bosne i Hercegovine, u dobi između 18 i 65 godina popunilo je nekoliko kratkih upitnika. Dimenzije afektivne vezanosti mjerene su Upitnikom za procjenjivanje odnosa $(R Q)$, afekti - Skalom negativnog i pozitivnog afekta (NAPAS), a psihološka fleksibilnost Upitnikom prihvatanja i akcije (AAQ-II). Rezultati pokazuju da dimenzija anksioznosti i dimenzija izbjegavanja pozitivno koreliraju sa negativnim afektom, a negativno sa pozitivnim afektom, kao i da se odnosi dimenzija afektivne vezanosti i negativnog afekta mogu objas-niti posredstvom psihološke fleksibilnosti, i to tako da više vri-jednosti na dimenzijama afektivne vezanosti doprinose slabijoj psihološkoj fleksibilnosti, što zatim rezultira snažnijim nega-tivnim afektom. Medijatorska uloga psihološke fleksibilnosti nije ustanovljena u relaciji dimenzije anksioznosti odnosno izbjegavanja i pozitivnog afekta. Dobijeni nalazi sagledani su u svjetlu teorijske i praktične važnosti.

Ključne riječi: dimenzije afektivne vezanosti, psihološka fleksibilnost, pozitivni i negativni afekat, odrasla dob 